\title{
TRUDNE DO WYKRYCIA MOTYWY SPRAWCÓW ZGWALCENIA
}

\begin{abstract}
Streszczenie. Artykuł poświęcony jest problematyce motywacji sprawców przestępstwa przeciwko wolności seksualnej - zgwałcenia. Źródłem atypowości opisywanych przez autorkę motywów jest stereotyp o seksualnych przyczynach przestępstw z art. 197 k.k., najczęściej nieznajdujący pokrycia w badaniach psychiatrycznych. Poznanie motywacji sprawców nie tylko wpływa pozytywnie na wykrywalność przestępstw, lecz także na przebieg prowadzonego postępowania, zarówno w procesie wyrokowania, jak i na etapie wykonania kary - resocjalizacji.
\end{abstract}

Slowa kluczowe: zgwałcenie, motywy, motywacja, biastofilia, parafilie, anger rape, power rape.

\section{ART. 197 KODEKSU KARNEGO - UWAGI OGÓLNE}

Przestępstwo zgwałcenia i doprowadzenia do innej czynności seksualnej znajduje penalizację w dyspozycji norm art. 197 § 1 i $\S 2$ ustawy z dnia 6 czerwca 1997 r. - Kodeks karny (t.j. Dz. U. 2016, poz. 1137 ze zm., dalej: k.k.). J. Warylewski wyłącza zgwałcenie z zakresu przestępstw przeciwko obyczajności, podnosząc, że dobry obyczaj reguluje zarówno sferę seksualności człowieka, jak i jego życie oraz zdrowie (Warylewski 2001, 25).

Już pobieżna lektura art. $197 \S 1$ i $§ 2$ k.k. skłania do konstatacji, że pojęcie zgwałcenia nie precyzuje czynów opisanych w przywołanych przepisach. Bliskoznaczność pojęciowa i etymologiczna zgwałcenia powoduje, że przestępstwo to kojarzone jest głównie z wykorzystaniem przemocy - gwaltu. Należy zwrócić uwagę na to, że przepis obejmuje znacznie szerszy zakres zachowań, również takich, które nie polegają na zastosowaniu przemocy fizycznej, a środkiem do doprowadzenia innej osoby do obcowania płciowego jest groźba bezprawna lub podstęp. Co więcej, nawet sam akt przemocy w stosunku seksualnym nie przesądza o tym, czy dane zachowanie jest zgwałceniem. $Z$ tego względu w doktrynie postuluje się zmianę brzmienia art. 197 § 3 k.k. poprzez zamianę pojęcia zgwałcenia w dyspozycji normy na „czyn określony w $§ 1$ lub 2”. Takie rozwiązanie prawne byłoby korzystne również z punktu widzenia nauk wiktymologicznych, według których terminologia zawarta w art. 197 k.k. powoduje stygmatyzację

* Uniwersytet Łódzki, Wydział Prawa i Administracji, Katedra Postępowania Karnego i Kryminalistyki,monika.janasik@gmail.com. 
ofiar, wobec których nie użyto przemocy podczas doprowadzania do obcowania płciowego i innej czynności seksualnej (Warylewski 2001, 21).

Przedmiotem ochrony jest wolność seksualna, rozumiana jako prawo jednostki do dysponowania własnym ciałem. Wyraża się ono w wolności wyboru partnera seksualnego, liczby partnerów, czasu, miejsca oraz formy stosunku seksualnego. Obejmuje również brak zgody prawnie skutecznej, jej modyfikacje i wychodzenie poza jej zakres (co ma duże znaczenie przy kontaktach seksualnych typu BDSM ${ }^{1}$ ). Zgoda dla swojej prawnej relewantności wymaga, by była wyrażona ex ante stosunku, w sposób czynny stanowić ekspresję woli jednostki, świadomie i swobodnie - wyklucza to działanie pod wpływem błędu, groźby bądź przymusu. Nie można traktować jako zgody braku pozytywnej decyzji ani utożsamiać z nią biernego zachowania ofiary, która nie broni się przed sprawcą. Nie ma znaczenia dla oceny niechęć, z jaką osoba pozwala na stosunek, zwłaszcza wobec wcześniejszych zachowań wywierających wrażenie, że takiej zgody udzieli (Sąd Apelacyjny w Krakowie w wyroku z dnia 23 marca 1994 r. w sprawie o sygn. akt II AKr 11/94). Problematyczne w kwestii ustalenia istnienia zgody są sytuacje, w których osoby utrzymywały pożycie przez dłuższy czas. Sąd Najwyższy w wyroku z dnia 14 marca 2017 r. w sprawie o sygn. akt IV KK 369/16, wskazał, iż koniecznym jest „dokonanie pogłębionej analizy dowodów dotyczących świadomości oskarżonego co do bezprawności jego zachowań w zakresie czynu z art. 197 § 1 k.k" Takie stanowisko Sądu potwierdza zobiektywizowanie wyrażenia zgody na stosunek seksualny i ocenę jej nie tylko w zakresie woli pokrzywdzonego, ale również świadomości sprawcy.

Przepis obejmuje ochroną każdą osobę, bez względu na płeć, orientację seksualną, budowę narządów płciowych. Odpowiedzialność karna sprawcy również jest niezależna od wymienionych cech, a zatem przestępstwo z art. 197 k.k. może popełnić także kobieta, choć według statystyk czynów takich jest znacznie mniej: od 2000 r. do 2010 r. podejrzanych było 130 kobiet, skazanych -80 , co daje $0,1 \%$ do 1,1\% ogółu skazanych (Mozgawa 2012, 282). Nie odnotowano zgwałcenia lesbijskiego (Mozgawa 2012, 281). Nie oznacza to jednak, że takie czyny się nie zdarzają. Zwłaszcza, że sam fakt zgwałcenia podlega ocenie z punktu widzenia prawnego, a nie zasadza się jedynie na subiektywnym odczuciu ofiary, zwłaszcza po zmianie trybu ścigania przedmiotowego przestępstwa w 2014 r. na ściganie ex officio. Oznacza to, że osoba może czuć się ofiarą przestępstwa zgwałcenia, mimo iż nie można przypisać sprawcy odpowiedzialności, bądź osoba nie czuje się pokrzywdzona, mimo iż de facto doszło do wypełnienia znamion czynu (Budyn-Kulik 2012, 244). Czasem ofiara zaś nie zgłasza popełnionego przestępstwa, ponieważ „nigdy nie słyszała, by ktoś zgłaszał coś takiego” (cytat z przeprowadzonej rozmowy).

${ }^{1}$ BDSM - Bondage and Discipline, Domination and Submission, Sadism and Masochism. Określa się w ten sposób praktyki seksualne polegające na krępowaniu, karaniu, dominacji i uległości, wreszcie - czynnościach sadomasochistycznych. 
Wątpliwości doktrynalne, wyrażające się także w braku jednolitej linii orzeczniczej, budzą pojęcia obcowania płciowego i innej czynności seksualnej. Obcowanie płciowe definiowane jest jako bezpośredni kontakt płciowych części ciała jednego z uczestników aktu z płciowymi częściami ciała drugiego uczestnika (Filar 2016, 1214). Na szczególną uwagę zasługują sytuacje mniej wyraźne, kiedy to sprawca posługuje się własnymi częściami ciała niebędącymi narządami płciowymi, a także surogatami narządów płciowych, ocenianymi z punktu widzenia sprawcy jako substytuty immisio penis. I tak, obcowaniem płciowym w orzecznictwie sądów jest wprowadzenie rąk do pochwy, ale już nie wibratora (tak: wyrok Sądu Apelacyjnego w Katowicach z dnia 9 listopada 2006 r. w sprawie o sygn. II Aka 323/06; wyrok Sądu Najwyższego z dnia 24 czerwca 2006 r., III KK 47/08; wyrok Sądu Apelacyjnego w Katowicach z dnia 19 kwietnia 2007 r., II AKa 40/07).

Inna czynność seksualna, o której stanowi art. 197 § 2 k.k. polega na zachowaniu niemieszczącym się w zakresie pojęciowym obcowania płciowego, ale nadal zachowaniu o charakterze seksualnym, do zaangażowania w które zmusza się ofiarę - fizycznie bądź intelektualnie (uchwała Sądu Najwyższego z dnia 19 maja 1999 r., sygn. I KZP 17/99; por. Filar 2016, 1215). Sąd Najwyższy w wyroku z dnia 26 października 2001 r. w sprawie o sygnaturze WA 25/01 uznał, że sama ingerencja w narządy płciowe ofiary nie wystarczy dla przypisania odpowiedzialności za zgwałcenie. W ocenie sądu celem sprawców były ,żart” i dezaprobata dla dokonanego przez pokrzywdzonego wyboru ścieżki kariery żołnierza zawodowego. W przedmiotowej sprawie doszło do ogolenia krocza i spryskania go płynem, co prowadziło również przy okazji do dotykania członka pokrzywdzonego (Kozielewicz 2012, 126). Sąd zważył, że zachowanie musi zmierzać do zaspokojenia lub pobudzenia popędu płciowego, by miało charakter seksualny. Nieostrość pojęciowa prowadzi do niepewności po stronie pokrzywdzonego, zwłaszcza patrząc przez pryzmat złożonej motywacji sprawców przestępstw seksualnych.

Nie budzi w orzecznictwie wątpliwości możliwość przypisania odpowiedzialności za przestępstwo zgwałcenia w sytuacji, gdy sprawca jedynie doprowadza ofiarę do określonego zachowania - sam zaś nie musi w nim uczestniczyć (tak: wyrok Sądu Apelacyjnego w Katowicach z dnia 16 maja 2002 r., II AKa 61/02). Karalne jest już podjęcie - rozpoczęcie przez sprawcę czynności obcowania płciowego, nawet gdy nie doszło do immisio penis (wyrok SA w Katowicach z dnia 30 listopada 2000 r., sygn. II AKa 308/00; w przedmiotowej sprawie sprawca położył się na pokrzywdzonej, ale nie doszło do pełnej realizacji zamiaru z powodu braku erekcji). Takie sformułowanie przepisów zazębia się z klasyfikacjami parafilii, choć zakresy penalizowanych zachowań i kategorii psychiatrycznych zazwyczaj nie są tożsame (Groth, Birnbaum 1979, 103; por. dalsze uwagi o zgwałceniu raptofilnym).

Znacznie trudniejszą do analizy od zbadania strony przedmiotowej czynu jest motywacja sprawcy. Motyw to uzasadniający dane działanie moment. Analiza zaś 
polega na „zbadaniu tego uzasadniającego momentu, na który składają się cechy związane z osobą sprawcy i aspekty sytuacyjne" (Hołyst 2009 325).

Poznanie motywów, jakimi kierował się sprawca, powinno być istotne nie tylko dla kryminologa badającego zjawisko przestępczości. Ustalenie motywów wpływa pozytywnie na określenie metodyki, ukierunkowania i celowość policyjnych dochodzeń (Hołyst 2009 326). Analiza motywów, już na etapie wykonywania kary, ma znaczenie dla zastosowania odpowiednich metod terapeutycznych dla sprawcy, by umożliwić realizację celów kary. Nie można pominąć znaczenia motywów również na etapie postępowania sądowego: wyroku dla sprawcy, wysokości kary, a nawet klasyfikacji karnoprawnej czynu.

Zbadanie motywu przysłużyłoby się też do rozwiania wątpliwości w przypadku konieczności rozstrzygnięcia, czy sprawca ma odpowiadać za przestępstwo popełnione w typie podstawowym (art. 197 § 1, 2 k.k.), czy w typie kwalifikowanym (art. 197 § 4 k.k.). Ustawa Kodeks karny nie definiuje znamienia szczególnego okrucieństwa. Interpretację wypracowuje orzecznictwo sądów powszechnych, które podaje dwa główne kryteria oceny. Pierwsze odnosi się do modus operandi sprawcy, drugie - skutku czynu. Tendencja do kładzenia nacisku na sposób działania sprawcy jako głównego kryterium wyraźnie zaznaczyła się w wyroku Sądu Najwyższego z dnia 17 grudnia 1970 r., IV KR 199/70. Poza ramy modus oprandi - wydaje się to słuszną, jak i ustaloną linią orzeczniczą - wychodzi Sąd Najwyższy w innych wyrokach. I tak, znamię szczególnego okrucieństwa stanowi wykroczenie poza niezbędną potrzebę do przełamania oporu ofiary (wyrok SN z dnia 9 kwietnia 1971 r., IV KR 33/71, OSNPG 1971/7-8 poz. 125). Nadto sądy zwracają uwagę również na cechy ofiary przestępstwa zgwałcenia oraz cel działania - poniżenie ofiary (co ma szczególne znaczenie przy ocenie przestępstw zgwałcenia w ramach tzw. hate crimes). W późniejszych latach doktryna i judykatura wypracowały kierunki interpretacyjne znamienia szczególnego okrucienstwa: w wyniku przestępstwa zgwałcenia zostaje wyrządzona znaczna dolegliwość fizyczna lub czyn pociąga za sobą następstwa w psychice ofiary:

- zastosowanie nadmiernych środków w stosunku do przełamania oporu ofiary,

- działanie sprawcy jest wymierzone nie tylko w naruszenie wolności seksualnej, ale również zmierza do poniżenia ofiary i zadania jej bólu,

- sposoby działania sprawcy można określić jako nieludzkie,

- dodatkowo Sąd Apelacyjny w Krakowie zwrócił uwagę na szczególne cechy spoczywające po stronie ofiary: wiek (małoletniość, ale również wiek starczy), nieporadność życiową, zaawansowaną ciążę, chorobę (por. wyrok Sądu Apelacyjnego w Gdańsku z dnia 25 stycznia 2001 r., II AKa 382/2000; wyrok Sądu Apelacyjnego w Krakowie z dnia 6 czerwca 2002 r., II AKa 110/2002, też: wyrok Sądu Najwyższego z dnia 27 czerwca 1997 r. WA 16/97 OSNKW 1997/11-12 poz. 97). 


\section{PRZYCZYNY AGRESJI SEKSUALNEJ}

Każde przestępstwo zmusza nas do podjęcia rozważań, dlaczego do niego doszło. Pytanie to dotyka nie tylko samych okoliczności popełnienia czynu, lecz także porusza problem tego, czy zło istnieje, skąd się bierze w człowieku, a przynajmniej - jak rodzi się agresja, będąca głównym katalizatorem negatywnych przejawów działalności człowieka. W literaturze, aby ująć w możliwe do objęcia rozumem ramy, skategoryzować oburzające nas działania, przeprowadza się taksonomie, typologie i klasyfikacje czynów. O ile taksonomie służą prawu - są pomocne dla wymiaru kar, oceny stopnia społecznej szkodliwości, o tyle typologie i klasyfikacje skupiają się na psychologicznym aspekcie przestępstwa (Pospiszyl 2014, 29). Podziały pomagają dotrzeć do motywacji sprawcy, co pozytywnie wpływa na jego wykrycie. Nie pozostaje to bez wpływu na jego resocjalizację, a także wymiar kary. Analiza typologii uznawanych przez psychologów jasno wskazuje, że motywacja sprawców zgwałceń jest o wiele bardziej złożona niż zaspokojenie własnego popędu płciowego w nieprawidłowy sposób. Wydaje się nawet, że niemożliwe jest, by do zgwałcenia doszło z powodów innych niż zaspokojenie popędu płciowego - bo czy można pragnąć zbliżenia, jakim niewątpliwie jest ingerencja w sferę seksualności drugiego człowieka, z kimś, do kogo czuje się niechęć, urazę, a nawet nienawiść?

W tle klasyfikacji przeplata się problem tkwienia skłonności (a także ich rozwoju) w osobie sprawcy: tego, kiedy zapoczątkowuje się w człowieku zło. Badacze skupieni wokół szkoły psychoanalizy odwołują się do prac Z. Freuda i jego koncepcji dotyczących superego i id, odpowiadających za prawidłowe ukierunkowywanie swoich popędów oraz hamowanie przestępczych skłonności. Powołuje się również na zaburzenia relacji między rodzicami a dzieckiem, w wyniku którego dochodzi do zaniku prawidłowych relacji interpersonalnych z pozostałymi ludźmi (R. Ressler, A. Burgess, za: Włodarczyk 2015, 50). Dodatkowo, następuje zderzenie czynników endogennych (tkwiących w osobie sprawcy) i egzogennych (dotyczących środowiska, w jakim sprawca się znalazł). Wśród czynników endogennych można wyróżnić: brak stabilizacji życia seksualnego (wyrażający się w braku partnerki, po uprzednich niepowodzeniach w życiu seksualnym), zwiększony popęd płciowy, dysproporcję między rozwojem fizycznym i hormonalnym a psychicznym, parafilie, zaburzenia psychiczne (związane $\mathrm{z}$ uzależnieniami i chorobami, urazami mózgu). Napotykają one czynniki egzogenne, wśród których wyróżnia się: zmiany społeczno-kulturalne (np. zmiana mody, liberalizacja zachowań seksualnych), zmiany w strukturze społecznej (związane z anonimowością dużych skupisk mieszkaniowych), brak opieki rodzicielskiej (ucieczki z domu), wpływ subkultur, nieprawidłowe wzorce, poczucie społecznego przymusu, patologie społeczne, mechaniczne uszkodzenia mózgu, błędy w profilaktyce (Włodarczyk 2015, 55). Do wymienionych czynników można dodać wpływ bodźców na zachowanie jednostki i swoiste jej zagubienie w świecie, w którym 
coraz trudniej dokonywać selekcji przyswajanych treści. Czynniki endogenne, napotykające szereg bodźców otaczającego świata, mogą doprowadzić do alienacji sprawcy w świecie fantazji, w którym znajdzie swój azyl i przyjemność. W efekcie dochodzi do warunkowania - uczenia się, co jest przyjemne, powstawania schematu postępowania (Money 1984, 166). Nacisk na warunkowanie jako główną przyczynę agresji seksualnej jest charakterystyczny dla badaczy skupionych wokół szkoły behawiorystycznej.

Klasyczna typologia zgwałceń, w oparciu o podstawowe czynniki zachowania, została opracowana w 1977 r. przez A. Nicholasa Grotha, A. Burgess i L. Holmstorm. W ich analizie sprawca dopuszczał się zgwałcenia kierowany złością (tu: anger rape), dominacją (power rape) bądź sadyzmem (gwałt sadystyczny). Każdy z tych rodzajów różni się modus operandi sprawcy, zwłaszcza stopniem brutalności. Anger rape charakteryzuje się wysokim stopniem brutalności. Stosunek w przypadku anger rape jest drogą do poniżenia osoby pokrzywdzonej. Przy tym rodzaju zgwałcenia często nie dochodzi do penetracji ze względu na brak wzwodu, nawet jeśli w normalnych sytuacjach nie pojawiają się takie zaburzenia (Pospiszyl 2014, 30; też: wyrok SA w Katowicach, II AKa 308/00).

Podobna motywacja dotyczy sprawców power rape, zgwałceń władczych. Sprawca dąży do udowodnienia swojej przewagi nad ofiarą - gwałt jest „desperackim poszukiwaniem utraconej wiary w siebie, próbą pozbycia się boleśnie odczuwanego poczucia beznadziejności, niekompetencji i ogólnego doświadczania małej wartości przez sprawcę" (Groth, Burgess, Holmstrom, 1977, cyt. za Pospiszyl 2014, 30). Sam czyn poprzedzony jest fantazjowaniem i szczegółowym planowaniem. Ten typ zgwałcenia jest wyrazisty dla prewencji, choć trudno przewidzieć, w którym momencie osoba dokona czynu. Sprawca często jednak zbliża się do wytypowanej przez siebie ofiary poprzez zadawanie pytań dotyczących jej doświadczeń seksualnych.

Również gwałt sadystyczny motywowany jest agresją - jest ,seksualną formą jej rozładowania" (Mosher 1991, cyt. za Pospiszyl 2014, 31). W tym typie zgwałcenia sprawca wybiera ofiary (często bowiem motywacja ta dotyczy sprawców seryjnych, przeradza się również w morderstwa z lubieżności) według przyjętego przez siebie klucza - ofiara ma cechy podobne do cech osób, które spowodowały głęboki uraz psychiczny we wcześniejszych fazach życia sprawcy.

Podział na anger rape i power rape stworzył podstawy do dalszych opracowań przedmiotowego zagadnienia. Rozwinął go R. Hazelwood, wprowadzając sześć podziałów: w miejsce power rape wprowadził zgwałcenia przywracające i potwierdzające władzę; anger rape - zgwałcenia złość-odwet i złość-podniecenie. Prócz tego wyróżnił zgwałcenie okazjonalne i zbiorowe. Znamienne, że również R. Hazelwood nie upatruje w gwałcie motywacji czysto seksualnej, a kładzie nacisk na to, że seks jest środkiem do osiągnięcia celu - wyładowania agresji i frustracji.

Inna klasyfikacja, kładąca nacisk na cechy psychiczne sprawców, została opracowana w Ośrodku Resocjalizacji w Massachusetts w 1990 r. przez 
A. Knighta i R. Prentky’ego. Wyróżnili oni: kompetencję społeczną (rozumianą jako dostosowanie społeczne sprawców; pogląd ten jest kwestionowany przez K. Pospiszyla; por. Pospiszyl 2014, 34), fantazje seksualne, sadyzm, cognitive distortion (tłumaczone jako ,wypaczenie myślenia”; w odczuciu autorki znacznie lepiej wyrażałoby to określenie miano „wypaczenia poznawczego”, „wypaczenia kognitywnego"), skłonność do dominacji, zaburzenia psychiczne mające źródło w uzależnieniach i chorobach (tamże).

Nieco rzadziej mówi się o zgwałceniu parafilicznym, wywołanym przez jeden z podtypów sadyzmu seksualnego, raptofilię (biastofilię). Raptofilia znalazła miejsce wśród parafilii w klasyfikacji DSM-III Amerykańskiego Towarzystwa Psychologicznego. Było to krytykowane ze względu na trudność rozróżnienia tego typu zgwałceń od zgwałceń pozostających poza parafiliami. W zgwałceniu takim sprawca jest ukierunkowany na przełamywanie oporu ofiary - osoby obcej, niespodziewającej się ataku i przerażonej, dopóki fantazje sprawcy nie znajdą ujścia (Money 1984, 166). Określanie raptofilii jako parafilii jest tym trudniejsze, iż psychiatryczne klasyfikacje zaburzeń seksualnych w DSM-V i ICD-10 nie podają jednak kryteriów, jakimi należy kierować się przy stawianiu diagnozy.

Szczególnym typem zgwałceń są te wpisujące się w ogólną grupę przestępstw z nienawiści (hate crimes). Odróżniane są od innych przestępstw ze względu na dobro, w jakie godzą - a jest nim identyfikacja ofiary $\mathrm{z}$ określoną grupą społeczną (Amerykańskie Towarzystwo Psychologiczne 1998, cyt. za Wesley 2012, 76). W tej kategorii możemy wyróżnić tzw. corrective rape (,gwałt naprawczy”). Określenie gwałt naprawczy powinno budzić niepokój, jako że sugeruje, iż przestępstwo może mieć pozytywne aspekty. Co więcej, należy zauważyć, że homoseksualizm został wykreślony z listy zaburzeń psychoseksualnych wraz z wydaniem DSM-III-R w 1987 r., co ostatecznie zostało zaaprobowane w 1990 r. przez WHO. Specyfikę opisywanego czynu znacznie lepiej oddaje pojęcie zgwatcenia z nienawiści. Kazuistyki dostarczyły sprawy zgwałceń lesbijek w południowej Afryce (choć nie można wykluczyć, że problem ten nie dotyka również Europy; czarna liczba jest trudna do ustalenia - zgwałcenia takie, a zwłaszcza ich motywy, bywają niewykryte ze strachu ofiar przed ujawnieniem istotnych szczegółów wiktymologicznych dotyczących orientacji seksualnej). Przebieg myślowy sprawcy można streścić słowami: „lesbijka nie wie, jak to jest być z mężczyzną, więc jej to pokażę i tym samym ją wyleczę" (Wesley 2012, 76).

Podobnie kształtuje się motywacja kobiet - sprawczyń zgwałceń. Analiza akt spraw (18, które zostały skierowane do sądów; oskarżonymi były 22 kobiety) z lat 2005-2011, przeprowadzona przez M. Mozgawę, pozwoliła wyodrębnić zgwałcenia z zemsty, np. za to, że z pokrzywdzoną zdradził sprawczynię mąż, a także w celu wymuszenia określonego zachowania, np. zaniechania odejścia z prowadzonej przez współsprawczynię agencji towarzyskiej (Mozgawa 2012, 300). 


\section{ITER DELICTI}

W doktrynie prawa karnego wyróżnia się etapy realizacji czynu zabronionego - formy stadialne przygotowania, usiłowania oraz dokonania przestępstwa. Kryminalistyka wychodzi nieco dalej, wskazując jako pierwsze na iter delicti sprawcy: fantazjowanie i zamiar. Choć w prawie karnym obowiązuje zasada niekarania za zamiar, w świetle wcześniejszych rozważań nie może budzić wątpliwości konieczność badania procesów psychicznych sprawcy.

Na gruncie badań psychologicznych wyróżniono trzy etapy cyklu przestępczego (warto nadmienić, że psychologia przy tym nie posługuje się prawniczymi określeniami form stadialnych przestępstwa, choć analiza cyklu przestępczego opracowanego przez A. Spencera wskazuje na to, iż w dużym zakresie one się pokrywają). Etapy te obejmują: uczucia, myślenie i działanie. Schemat ten został rozbudowany przez A. Spencera, który wyodrębnił trzynaście etapów, które obrazuje rys. 1.
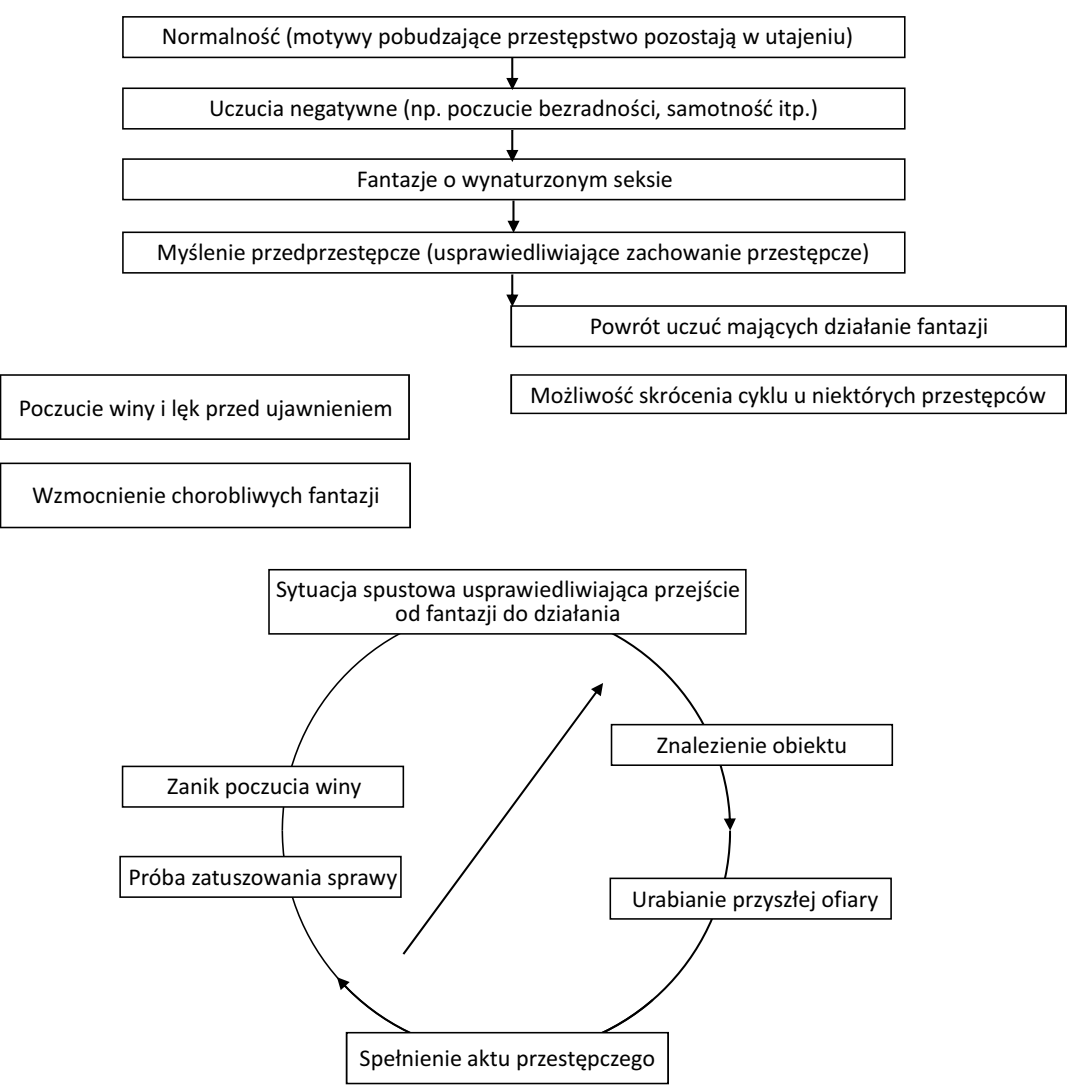

Rys. 1. Cykl przestępstwa seksualnego według A. Spencera, 1999 r.

Źródło: Pospiszyl 2014, 133 
Pierwsza część rysunku, zawierająca stadia od 1 (normalność) do 4 (myślenie przedprzestępcze), obejmuje etap zanim osoba stała się sprawcą przestępstwa. Etap ten zaczyna się od normalności, czyli zachowania przeciętnego, nieodbiegającego od norm społecznych, przykładnego. Następująca po nim kumulacja uczuć negatywnych jednostki (krzywdy, frustracji), prowadzi do powstania fantazji o dominacji nad innymi; ich skrajnym wyrazem stają się fantazje seksualne o absolutnej uległości (Pospiszyl 2014, 131).

Spostrzeżenia A. Spencera pokrywają się z badaniami na gruncie kryminalistyki dotyczącymi seryjnych morderstw (wszak morderstwo jest skrajnym przejawem sadyzmu, a ten jest parafilią). T. Hanausek wypracował teorię - syndrom PKW - opartą na współoddziaływaniu: predyspozycji (biologicznych uwarunkowań), krzywdy i wpływu czynników środowiskowych. Podobną koncepcję, nazwaną zespołem ZSF, stworzył Ł. Wroński. Określił przy tym cechy, które skumulowane, doprowadzają osobę do zostania sprawcą: zaburzenia psychiczne (głównie zaburzenia osobowości), sadystyczne tendencje, nagromadzone frustracje (Wroński 2016, 188).

Kolejnym spostrzeżeniem A. Spencera była powtarzalność zachowań sprawców przestępstw seksualnych: w momencie wystąpienia sytuacji spustowej nastąpiła reakcja o charakterze "samonapędzającego się mechanizmu błędnego koła" (Pospiszyl 2014, 134). Można upatrywać w tym specyficznej formy uzależnienia od popełniania przestępstwa - w umyśle sprawcy zachowania nastawionego na natychmiastową, choć krótkotrwałą, gratyfikację.

\section{WNIOSKI}

Badanie spraw zgwałceń, sprawców, wreszcie - obłożonych swoistym kulturowym tabu - ich ofiar wciąż nie jest zadaniem łatwym, mimo że upłynęło już wiele lat od czasów rewolucji seksualnej w Ameryce, późniejszych prac naukowych seksuologów i kryminologów. Powstające typologie oraz kategoryzacje czynów wydają się wypadkową ugruntowanych wcześniej teorii - nie oznacza to jednak zacofania naszej wiedzy ani podążania z łatwością utartymi ścieżkami. Oznacza to, że mentalność ludzka na przestrzeni dziejów nie zmienia się znacznie: wciąż jesteśmy zależni od naszych uwarunkowań biologicznych, ulegamy wypadkom, czynnikom endogennym, jak by to określili psychologowie. Zmieniają się nasze czynniki egzogenne, liczba bodźców, które nas otaczają, trudność w ich selekcji - to de facto warunkowanie naszych odruchów.

Nadal trzeba przełamywać opór ofiary - strach przed ujawnieniem szczegółów życia, budować zaufanie do osoby śledczego, zwłaszcza w sprawach tak delikatnych, jakimi są zgwałcenia z nienawiści. Należy ciągle zapobiegać wiktymizacji ofiary przestępstwa (co nie znaczy, że jej osoba nie wniesie niczego prócz dowodów do postępowania; badanie tzw. winy wiktymologicznej, której 
nie wolno utożsamiać z odpowiedzialnością za czyn, pozwala wyodrębnić cechy, których poznanie wpłynie pozytywnie na prewencję przestępczości). A przede wszystkim - co podkreślają psychologowie - należy skończyć z utożsamianiem przestępstw przeciwko wolności seksualnej z zaspokajaniem popędu płciowego sprawcy, na co wskazuje analiza motywów, jakimi kierują się sprawcy zgwałceń.

\section{BIBLIOGRAFIA}

Budyn-Kulik, Magdalena. 2012. „Wybrane wiktymologiczne (i psychologiczne) aspekty zgwałcenia”. W Przestępstwo zgwatcenia. Red. Marek Mozgawa. 243-280. Warszawa: Wolters Kluwer.

Choromańska, Agnieszka, Dorota Mocarska. 2009. Dewiacje i przestępstwa seksualne - klasyfikacja, aspekty prawne. Szczytno: Wydawnictwo Wyższej Szkoły Policji.

Filar, Marian. 2016. Kodeks karny. Komentarz. Warszawa: Wolters Kluwer.

Groth, Nicholas, Jean Birnbaum. 1979. Men Who Rape. The Psychology of the Offender. New York: Plenum Press.

Hołyst, Brunon. 2009. Kryminologia. Warszawa: LexisNexis.

Kowalczyk, Małgorzata. 2014. Przestępcy seksualni. Zabójcy, gwatciciele, pedofile i ich resocjalizacja. Torun: Wydawnciwto UMK.

Kozielewicz, Wiesław. 2012. „Pojęcia: »czyn nierządny«, »czyn lubieżny«, »obcowanie płciowe« i »inna czynność seksualna« w orzecznictwie Sądu Najwyższego". W Przestępstwo zgwatcenia. Red. Marek Mozgawa. 117-128. Warszawa: Wolters Kluwer.

Lew-Starowicz, Zbigniew. 2000. Seksuologia sadowa. Warszawa: PZWL.

Money, John. 1984. „Paraphilias: Phenomenology and Classification”. American Journal of Psychotherapy. 164-179. http://reddragdiva.co.uk/lj/money\%20paraphilias\%20content\%20and\%20 classification.pdf [dostęp 15.12.2016].

Mozgawa, Marek (red.). 2012. Przestepsstwo zgwałcenia. Warszawa: Wolters Kluwer.

Pospiszyl, Kazimierz. 2014. Przestępstwa seksualne. Warszawa: PWN.

Warylewski, Jarosław. 2001a. Przestępstwa przeciwko wolności seksualnej i obyczajności. Rozdziat XXV Kodeksu karnego. Komentarz. Warszawa: C.H. Beck.

Warylewski, Jarosław. 2001b. Przestęstwa seksualne. Gdańsk: Wydawnictwo Uniwersytetu Gdańskiego.

Wesley, Tiffani. 2012. „Classifying ‘Corrective' Rape: A Call for Justice”. BUWA! A Journal on African Women's Experiences: 75-81. http://www.osisa.org/sites/default/files/75-81.pdf [dostęp 15.12.2016].

Włodarczyk, Renata. 2015. Kryminalistyczno-kryminologiczne aspekty przestępstw na tle seksualnym. Szczytno: Wydawnictwo Wyższej Szkoły Policji.

Wroński, Łukasz. 2016. Seryjni i wielokrotni mordercy. Profilowanie psychologiczne i psychogeograficzne. Łomianki: Centrum Psychologii Kryminalnej. 
Monika Janasik

\title{
RAPISTS' MOTIVES HARD TO DISCOVER
}

\begin{abstract}
The article focuses on issues of motives of sexual offenders i.e. rapists. The source of atypicality of motives described by the author is a stereotype of sexual reasons for crimes under art. 197 of the Polish Criminal Code, which are not confirmed in psychiatric studies. The cognition of rapists' motives has a positive influence not only on crime detection but also on the proceedings at the stage of judgment passing and carrying out the penalty (resocialization).
\end{abstract}

Keywords: rape, motives, motivation, biastophilia, paraphilia, anger rape, power rape. 